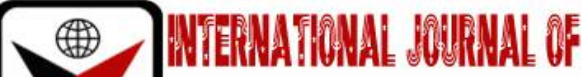



ISSN 2278 - 0211 (Online)

\section{Seasonal Variations in Physicochemical Properties of Water Quality of Sosiani River -Eldoret, Kenya}

\author{
Francis Ongachi Olal \\ Senior Lecturer, Department of Physical Sciences, Rongo University, Kenya
}

\begin{abstract}
:
Water pollution is the change in physico-chemical and biological properties of water quality that is harmful to living things. It is caused by pollutants drawn from domestic, industrial and agricultural effluents. It can also be caused by inappropriate use of chemicals and haphazard disposal of waste. It has become a global concern due to effects on fauna and flora. Sosiani River traverses Eldoret town, draining effluent openly discharged. This river is an important source of industrial and domestic water for residents living in Eldoret, Turbo towns. The study assessed seasonal variations in physicochemical properties of river water. Water samples were collected from five (5) sampling points along Sosiani River for six months and analyzed using American Public Health Association water sampling and processing procedures. Data was managed using Statistical Packages for Social Sciences version 20. Both descriptive and inferential statistics like analysis of variance, correlation and regression analysis were used in analysing the resultant data. Sosiani River exhibited high mean levels of turbidity at $32.6 \pm 17.0 \mathrm{NTU}$, high biological oxygen demand at $61.9 \pm 22 \mathrm{mg} / \mathrm{L}$, high chemical oxygen demand at $110.6 \pm 39.0 \mathrm{mg} / \mathrm{L}$, high total suspended solids at $135 \pm 41.5 \mathrm{mg} / \mathrm{L}$, high total dissolved solids at $160.0 \pm 41.1 \mathrm{mg} / \mathrm{L}$. The physico-chemical properties of water quality varied significantly along Sosiani River and with changing seasons at $P<0.005$. The physico-chemical water parameters increase in concentration along the river up to midstream in town centre but decline downstream along the river up to Turbo town.
\end{abstract}

Keywords: Physicochemical, Sosiani, water quality, pollutants

\section{Introduction}

Surface waters are vital sources of freshwater for domestic use globally. They provide freshwater resources, water for irrigation, hydropower and recreation purposes. Also, rivers play an important role in assimilation of domestic and industrial wastewater through complex processes. The processes include; sedimentation, coagulation, volatization, among others (McKinney \& Schoch, 2003). But rivers have become susceptible to pollution as water bodies become dumping grounds of effluent and solid waste. Rivers have also been used as sinks for urban effluent and therefore becoming a pathway for heavy metal translocation worldwide (McKinney \& Schoch, 2003). Aquatic organisms accumulate these pollutants from contaminated water and through bioaccumulation in the food chain posing a threat to human and ecosystem. Owing to the large quantity of effluents discharged to the receiving waters, the natural processes of contaminant removal or reduction are inadequate to reduce pollution. Therefore some rivers are unable to self purify as waters flow downstream (Maina et al., 2010). Water pollution has become a global problem as effluent management deteriorates with increasing populations, urbanization and industrialization. (Burton \& Robert, 2001; McKinney \& Schoch, 2003; Hogan, 2010).

Effluent discharge alters the physico-chemical properties of water quality which interferes with vital water use, ecosystem functions and human health. Water pollution can then be defined as the change in physical, chemical and biological properties of water quality that has harmful effect on living things (WHO, 2016). Water supports life and it is important that drinking water be clean and safe (Goel, 2006; Hogan, 2010; WHO, 2011). Most water resources are polluted by non-point source where pollutants gradually diffuse or leach into rivers. Water pollution then limits water use which in turn aggravates water scarcity and also imposes a higher cost for water treatment. Decreasing water quality has become an environmental concern. (Goel, 2006; Hogan, 2010; WHO, 2017).

Water quality will differ from place to place depending on seasonal changes, types of soils and rocks (Trivede et al., 2010; Vaishali \& Punita, 2013; Seth et al., 2014; Thivya et al., 2014). Again, anthropogenic activities alter the natural composition of water through disposal of chemicals, wastes, municipal effluent and industrial discharges (Moyo, 2013; 2014; Bello, 2015). 


\subsection{Physico-Chemical Parameters}

\subsubsection{Temperature}

Temperature has influence on living and non-living components of the environment as it affects organisms and functioning of ecosystems (Hogan, 2010). High water temperatures affect chemical and biochemical reactions; reduce respiration rate, reproduction and survival of aquatic organisms. Elevated temperatures also affect solubility of gases, minerals and nutrients in water. High water temperatures decrease dissolved oxygen in water

\subsubsection{Water $\mathrm{pH}$}

$\mathrm{pH}$ is the negative logarithm to base 10 of the hydrogen ion concentration. It is the presence of salts of weak acids like bicarbonate, carbonate and hydroxide ions which contribute to high water $\mathrm{pH}$. They are key water quality parameters that greatly influence chemical coagulation, disinfection, softening processes and corrosion control in water distribution pipe networks. Effective chemical coagulation of water occurs only within a specific pH range (Goel, 2006). The pH of most natural waters varies from 6.0 - 8.5 while $\mathrm{pH}$ for seawater varies from 7.5-8.4. Water $\mathrm{pH}$ depends on the acid base equilibrium achieved by various salts and gases dissolved in it (Goel, 2006).

\subsubsection{Turbidity}

Turbidity compares intensity of light scattered by a water sample and a standard reference suspension measured in Nephetometric Turbidity Units (NTU). The higher the intensity of light scattered, the higher the turbidity. It is caused by suspended matter like clay, silt, among others (Kudret \& Ilker, 2011). The impact of suspended sediments is increased light attenuation through water. High turbidity decreases algal growth and productivity of aquatic ecosystems which affects feeding of fish. It also reduces photosynthesis and visual range of sighted animals.

High turbidity in water for domestic use can reduce the efficiency of water disinfection since it offers protection to microorganisms. To have efficient disinfection, turbidity must be reduced to 1NTU through coagulation, sedimentation and filtration (WHO, 2011).

\subsubsection{Total Dissolved Substances}

Water dissolves a wide range of substances. These total dissolved solids (TDS) beyond a certain concentration in water impair aesthetic properties of water which gives it an earthy taste.. Drinking water becomes increasingly unpalatable when total dissolved substances exceed $1000 \mathrm{mg} / \mathrm{L}$.

\subsubsection{Biological Oxygen Demand (BOD)}

Biological oxygen demand (BOD) is a measure of the amount of biologically oxidizable organic matter present in a water body (McKinney \& Schoch, 2003; Mosley et al., 2004; Goel, 2006). It gives the amount of oxygen that aerobic bacteria could consume in the process of decomposing all the organic matter available to them. High BOD means low levels of dissolved oxygen which gives stress to aquatic organisms. (McKinney \& Schoch, 2003; Mosley et al., 2004; Goel, 2006). Biological oxygen demand (BOD5) is a five day incubation period adopted as standard experimental procedure. The more the organic matter the greater the demand on oxygen.

\subsubsection{Chemical Oxygen Demand (COD)}

Chemical oxygen demand (COD) is a measure of both the amount of overall biologically degradable and chemically oxidizable organic matter in water samples. It is determined by the open reflux dichromate method using potassium dichromate as oxidizing agent, in a strong acidic media. Chemical oxygen demand measures all organic contaminants including those that are not biodegradable. High COD levels imply the presence of organic material in water which reduces dissolved oxygen. A reduction in dissolved oxygen is dangerous to aquatic life as they suffocate and eventually die (McKinney \& Schoch, 2003; Mosley et al., 2004; Vanloon \& Duffy, 2005; Goel, 2006). High chemical oxygen demand also shows presence of organic and inorganic matter which is not biodegradable (McKinney \& Schoch, 2003; Clescerl, 2008).

\section{Materials and Methods}

\subsection{Study Area}

Sosiani River traverses Eldoret town in Uasin Gishu County of Kenya. It originates from the Two River dam in Kipkurgot, a confluent of two streams namely Elengerini and Endoroto, whose source is Kaptagat forest in the highlands of Keiyo escarpment. Sosiani River then flows through Eldoret town and drains into Kipkaren Rive. The study was conducted in a stretch of approximately $40 \mathrm{Km}$, from the source of the river at Two River dam through Eldoret town to Turbo town. Sampling sites were selected as follows: 1 . Two rivers dam, 2. Sukunanga carwash, 3. Eldoret market, 4. Huruma sewage treatment plant discharge point, 5. Turbo town. Eldoret can be said to be a river valley town where surface runoff drains into Sosiani River. It is an agricultural town with large scale farming of wheat and maize and therefore the use of agrochemicals is a major environmental concern to the Sosiani River. Eldoret is a commercial town in the North Rift region and has attracted a large urban population. Therefore, urban migration constraints provision of social amenities like clean drinking water and sewerage system to residents of the town. 


\subsection{Water Sampling and Analysis}

\subsubsection{Sampling}

Samples were collected at five (5) points along Sosiani River once per month for a period of six months in 2019, from January to June, covering dry season (January to March) and wet season (April to June). Composite samples were collected using half litre bottles at a depth of $0.5 \mathrm{~m}$ below water surface. Samples for heavy metals were acidified with concentrated nitric acid to minimize precipitation and adsorption of metals on container walls. Samples were refrigerated and stored in the dark.

\subsubsection{Sample Analysis}

Turbidity was measured using a HACH 2100A Turbidimeter with a photoelectric detector. Formazin polymer was used as a standard reference suspension.

Water $\mathrm{pH}$ and temperature was measured in-situ using Wagtech portable meter calibrated against a buffer solution of $\mathrm{pH}$ 4, 7 and 10 units. Electrode was rinsed with distilled water and dried before inserting into the water. Readings were taken one minute after the meter had stabilized (APHA, 2017).

Water sample of one litre was filtered using glass fibre filter of pore size $0.45 \mu \mathrm{m}$ and refrigerated at $1-4^{\circ} \mathrm{C}$. The total suspended solids (TSS) were determined by drying the filtrate at $103-105^{\circ} \mathrm{C}$ then weighed within 24 hours (APHA, 2017). Total suspended solids were computed using the formula: Suspended solids in $\mathrm{mg} / \mathrm{L}=$ Finalweight-Initialweight $\times 1000$ Volumeof sampleused

For total dissolved solids (TDS), one litre of the water sample was filtered through ordinary filter paper and water collected in an evaporating dish of known weight. The dish was heated to evaporate the water. The dissolved solids which accumulated at the bottom of the dish were then weighed (APHA, 2017).

Biological Oxygen Demand (BOD)was determined in accordance with standard procedure 5210B (APHA 2017) referred to as $\mathrm{BOD}_{5}$ test method. The chemical oxygen demand (COD) was determined by use of the open dichromate reflux method (APHA, 2017).

\subsubsection{Data Analysis}

Data collected was captured in Excel spreadsheet for Windows XP, and then organized, coded and summarized using descriptive statistics. The means, variance and standard error were used to analyse the spread of this data. The data was analysed with the help of Statistical Packages for Social Sciences Statistics (SPSS). Variations in water quality parameters were determined using inferential statistics (Mugenda \& Mugenda, 2003; Michael \& Douglas, 2004; Yolanda \& Zayas, 2007).

The mean of parameters $\pm \mathrm{SE}$ and one-way analysis of variance were used to determine and compare any significant differences among the mean values of parameters along the Sosiani River. The differences in mean values were considered significant when calculated P-values were $<0.05$.

\section{Results and Discussion}

\subsection{Sources of Water Pollution along Sosiani River}

There are many effluent discharge points from hotels and industries which are located along Sosiani River that affect the physico-chemical properties of water quality of the river. Sources of effluent discharged into Sosiani River contributing to water contamination include Zena Flower Farm located near Two River Dam, Carbacid factory, Sukunanga carwash along the Eldoret-Nairobi highway, Moi Teaching and Referral Hospital, St Lukes Hospital, several hotels, Eldoret market, motor vehicle garages at Bundaptai, Oldonyo-Lessos dairy factory, Rai plywood wood processing factory and Huruma sewage treatment plant. These effluent discharge points ultimately affect the physicochemical properties of water quality of Sosiani River in Eldoret.

\begin{tabular}{|c|c|c|c|c|c|c|c|c|}
\hline Site & $\begin{array}{c}\text { TSS } \\
\mathbf{m g} / \mathbf{L}\end{array}$ & $\begin{array}{c}\text { TDS } \\
\mathbf{m g} / \mathbf{L}\end{array}$ & $\begin{array}{c}\text { TEMP } \\
\mathbf{o} \mathbf{C}\end{array}$ & $\begin{array}{c}\mathbf{p H} \\
\mathbf{p H} \\
\mathbf{U n i t s}\end{array}$ & $\begin{array}{c}\mathbf{D O} \\
\mathbf{m g} / \mathbf{L}\end{array}$ & $\begin{array}{c}\text { TURB } \\
\text { NTU }\end{array}$ & $\begin{array}{c}\text { BOD } \\
\mathbf{m g} / \mathbf{L}\end{array}$ & $\begin{array}{c}\text { COD } \\
\mathbf{m g} / \mathbf{L}\end{array}$ \\
\hline $\begin{array}{c}\text { Two River } \\
\text { Dam }\end{array}$ & $5.3 \pm 2.8$ & $26.5 \pm 8.7$ & $21.1 \pm 1.5$ & $7.2 \pm 0.1$ & $11.0 \pm 2.1$ & $10.8 \pm 4.3$ & $15.7 \pm 5.9$ & $22 \pm 8.2$ \\
\hline $\begin{array}{c}\text { Sukunanga } \\
\text { Carwash }\end{array}$ & $17.4 \pm 9.3$ & $34.8 \pm 6.2$ & $22.8 \pm 1.1$ & $7.3 \pm 0.3$ & $7.7 \pm 1.7$ & $39.1 \pm 36.9$ & $62.1 \pm 47.9$ & $89.8 \pm 65.6$ \\
\hline $\begin{array}{c}\text { Eldoret } \\
\text { market }\end{array}$ & $16.0 \pm 9.3$ & $43.8 \pm 17.4$ & $19.9 \pm 0.2$ & $7.3 \pm 0.2$ & $7.8 \pm 2.1$ & $47.4 \pm 38.4$ & $81.1 \pm 72.6$ & $193.2 \pm 155$ \\
\hline $\begin{array}{c}\text { Huruma } \\
\text { Sewage } \\
\text { works }\end{array}$ & $51.3 \pm 23.6$ & $326.3 \pm 89$ & $27.3 \pm 0.7$ & $8.5 \pm 0.1$ & $7.2 \pm 1.6$ & $112.3 \pm 56.3$ & $288.4 \pm 184$ & $359.4 \pm 182$ \\
\hline $\begin{array}{c}\text { Turbo } \\
\text { town }\end{array}$ & $42.8 \pm 25$ & $81.5 \pm 37.4$ & $19.8 \pm 0.8$ & $7.3 \pm 0.1$ & $11.8 \pm 2.3$ & $62.6 \pm 41.9$ & $63.8 \pm 52.4$ & $88.8 \pm 71$ \\
\hline $\begin{array}{c}\text { Overall } \\
\text { mean }\end{array}$ & 26.6 & 102.5 & 22.2 & 7.5 & 9.1 & 54.4 & 102.2 & 150.6 \\
\hline
\end{tabular}

Table 1: Means of Physicochemical Parameters along Sosiani River 


\subsection{Seasonal Variations of Total Suspended Solids (TSS)}

The mean TSS for the wet season was $194.6 \mathrm{mg} / \mathrm{L}$, higher than the TSS for the dry season of $76.1 \mathrm{mg} / \mathrm{L}$. T-statistic is greater than $\mathrm{t}$-critical at $\mathrm{t}=1.57$ and $\mathrm{P}<0.014$ hence there was significant seasonal variation in TSS at $95 \%$ confidence limit as seen in Table 3. Increase in total suspended solids during the onset of the rainy season could be attributed to increased surface run off. On average the mean monthly TSS for Sosiani River is above NEMA guidelines (30mg/L).

\begin{tabular}{|l|l|l|l|l|l|l|l|l|}
\hline Month & \multicolumn{1}{|c|}{ TSS mg/L } & TDS mg/L & TEMP ${ }^{-C}$ & pH & DO mg/L & $\begin{array}{c}\text { TURB } \\
\text { (NTU) }\end{array}$ & BOD mg/L & COD mg/L \\
\hline Jan & $168.9 \pm 114.8$ & $171.5 \pm 41.8$ & $23.8 \pm 2.9$ & $7.1 \pm 0.6$ & $9.2 \pm 1.7$ & $35.7 \pm 30$ & $58.8 \pm 57.8$ & $92.5 \pm 86.7$ \\
\hline Feb & $158.2 \pm 109.0$ & $165.1 \pm 41.1$ & $23.7 \pm 2.6$ & $7.2 \pm 0.6$ & $9.7 \pm 1.8$ & $24.4 \pm 20.7$ & $46.0 \pm 46.0$ & $66.9 \pm 64.3$ \\
\hline Mar & $142.5 \pm 96.2$ & $155.8 \pm 40.1$ & $23.6 \pm 2.6$ & $7.2 \pm 0.6$ & $10.5 \pm 1.7$ & $13.4 \pm 12.2$ & $31.7 \pm 31.3$ & $46.3 \pm 43.6$ \\
\hline Apr & $128.5 \pm 84.9$ & $152.1 \pm 40.0$ & $22.5 \pm 2.7$ & $7.2 \pm 0.6$ & $9.7 \pm 1.5$ & $25.2 \pm 16.2$ & $42.2 \pm 35.3$ & $105.2 \pm 105$ \\
\hline May & $133.2 \pm 86.4$ & $154.9 \pm 40.3$ & $22.3 \pm 2.9$ & $7.1 \pm 0.5$ & $8.7 \pm 1.9$ & $38.6 \pm 22.0$ & $75.2 \pm 62.5$ & $133.7 \pm 103$ \\
\hline Jun & $187 \pm 41.5$ & $165.2 \pm 41.1$ & $22.0 \pm 3.3$ & $7.1 \pm 0.6$ & $8.2 \pm 1.7$ & $58.0 \pm 27.0$ & $117.6 \pm 82$ & $219.0 \pm 49.1$ \\
\hline $\begin{array}{l}\text { Overall } \\
\text { mean }\end{array}$ & 135.1 & 160.8 & 23.0 & 7.2 & 9.3 & 32.6 & 61.9 & 110.6 \\
\hline
\end{tabular}

Table 2: Monthly Means of Physico-Chemical Parameters

\subsection{Seasonal Variations in Total Dissolved Solids (TDS)}

The mean monthly TDS at $102.5 \mathrm{mg} / \mathrm{L}$ was below the NEMA and WHO guidelines. The mean TDS during dry season was $98.2 \mathrm{mg} / \mathrm{L}$ andin wet season was $179.8 \mathrm{mg} / \mathrm{L}$. The $\mathrm{t}$-statistic at $\mathrm{t}=4.49, \mathrm{P}<0.001$ is greater than $\mathrm{t}$-critical. Hence there was significant variation in mean monthly total dissolved substances at $99 \%$ confidence limit. This could be attributed to increased surface runoff refer to Table 3.

Dissolved solids increase electrical conductivity, BOD and turbidity of water (Muchukuri et al., 2014, Bello et al., 2015).

\begin{tabular}{|c|c|c|c|c|c|}
\hline Parameter & $\begin{array}{c}\text { Mean Dry } \\
\text { Season }\end{array}$ & $\begin{array}{c}\text { Mean Wet } \\
\text { Season }\end{array}$ & $\begin{array}{c}\text { Mean } \\
\text { Difference }\end{array}$ & T-Statistics & P Value \\
\hline TEMP oC & $23.7 \pm 2.6$ & $22.6 \pm 3.1$ & $1.1 \pm 0.9$ & 4.39 & 0.001 \\
\hline $\mathrm{pH}$ (pH Units) & $7.2 \pm 0.6$ & $7.1 \pm 0.6$ & $0.1 \pm 0.05$ & 0.19 & 0.849 \\
\hline DO mg/L & $9.3 \pm 2.0$ & $7.1 \pm 2.1$ & $2.2 \pm 0.6$ & 12.7 & $<.001$ \\
\hline TURB(NTU) & $31.1 \pm 32.6$ & $80.3 \pm 54.2$ & $-49.2 \pm 20.1$ & -8.86 & $<.001$ \\
\hline BOD mg/L & $53.9 \pm 59.1$ & $156.2 \pm 133.2$ & $-102.3 \pm 57.7$ & -6.46 & $<.001$ \\
\hline COD mg/L & $84.0 \pm 87.6$ & $264.0 \pm 198.9$ & $-180.0 \pm 89.0$ & -7.35 & $<.001$ \\
\hline TSS mg/L & $76.1 \pm 196.2$ & $194.6 \pm 383.5$ & $-108.5 \pm 58.8$ & -1.57 & $<.0142$ \\
\hline TDS mg/L & $98.2 \pm 87.5$ & $179.8 \pm 140.1$ & $-81.6 \pm 46.9$ & -4.49 & $<.001$ \\
\hline
\end{tabular}

Table 3: Comparison of Mean Parameters between Wet and Dry Season

\subsection{Seasonal Variations of Water Temperature}

The mean monthly water temperature in Sosiani River during the dry season was $23.7^{\circ} \mathrm{C}$. Mean temperature during the wet season was $22.6^{\circ} \mathrm{C}$. The $\mathrm{t}$-statistic $\mathrm{t}=4.39, \mathrm{P}<0.001$ is greater than the $\mathrm{t}$-critical at $99 \%$ confidence limit. Hence temperature in Sosiani River varied significantly from dry to wet season.

\subsection{Seasonal Variations of Turbidity}

Mean turbidity during the dry season was $31.1 \pm 32.6 \mathrm{NTU}$. Mean turbidity during the rainy season was $80.3 \pm$ 54.2NTU. The $\mathrm{t}$-statistic at $\mathrm{t}=8.86, \mathrm{P}<0.001$ is greater than the $\mathrm{t}$-critical at $99 \%$ confidence limit. Hence there was significant seasonal variation in turbidity during the dry and wet season in Sosiani River. This could be attributed to increased surface runoff refer to Table3.3. Increased surface runoff during the wet season washes down sediments into the river which increases suspended matter.

\subsection{Seasonal Variations of Biological Oxygen Demand (BOD)}

The mean BOD during the dry season was $53.9 \mathrm{mg} / \mathrm{L}$ and in the wet season was $156.2 \mathrm{mg} / \mathrm{L}$. The $\mathrm{t}$-statistic at $\mathrm{t}=$ $6.46, \mathrm{p}<0.001$ is greater than the $\mathrm{t}$-critical at $99 \%$ confidence limit. Hence there was significant variation in BOD at $99 \%$ confidence limit. This is attributed to high runoff during the wet season which washes organic matter into the River and increases bacteria activity to biodegrade the matter hence an increase in oxygen demand Table 3.

High biological oxygen demand stresses aquatic organisms. The rainy season increases surface runoff that drains more sediments and organic matter into the river. This increases microbial activity to oxidize the excess organic matter drained into the river hence the increased biological oxygen demand.

\subsection{Seasonal Variations of Chemical Oxygen Demand (COD)}

The mean COD for the dry season was $84 \mathrm{mg} / \mathrm{L}$ and during the wet season was $264 \mathrm{mg} / \mathrm{L}$. The t- statistic at $\mathrm{t}=7.35$, $\mathrm{P}<0.001$ is greater than the $\mathrm{t}$-critical at $99 \%$ confidence limit. Hence there was significant seasonal variation in mean chemical oxygen demand in Sosiani River during the dry and wet seasons Table 3. This could be attributed to increased 
surface runoff washing in effluent and organic matter during the wet season. High chemical oxygen demand shows that there is high overall biologically degradable matter and chemically oxidizable organic matter.

\subsection{Seasonal Variations of Dissolved Oxygen (DO)}

The DO in Sosiani River varied with changes in rainy season. The mean dissolved oxygen for the dry season was $9.3 \pm 2.0 \mathrm{mg} / \mathrm{L}$ and that of the wet season was $7.1 \pm 2.1 \mathrm{mg} / \mathrm{L}$. The $\mathrm{t}$-statistic at $\mathrm{t}=12.7, \mathrm{P}<0.001$ is greater than the $\mathrm{t}$ critical at $99 \%$ confidence limit. Hence there was significant seasonal variation in dissolved oxygen in Sosiani River during the wet and dry season. Low dissolved oxygen in dry season could be attributed to increased temperatures which reduces dissolved oxygen in water. It was evident that dissolved oxygen was lowest where BOD, COD and Turbidity were highest.

\section{Conclusions and Recommendations}

\subsection{Conclusions}

Human activities contributing to impairment of water quality in Sosiani River were found to be agrochemicals from Zena flower farm effluent, waste oils from Sukunanga carwash, storm water from county market of Eldoret, Hospital waste, hotels, motor vehicle garages, and discharge from Huruma wastewater treatment plant. They discharge varying types of pollutants into Sosiani River affecting water quality.

The physico-chemical properties of water quality varied significantly along Sosiani River and with changing seasons. The physico-chemical water parameters increase in concentration as more effluent is discharged midstream in town centre but decline downstream along the river up to Turbo town. Turbidity, total suspended solids, chemical oxygen demand and biological oxygen demand were above the NEMA standard guidelines while total dissolved substances were below NEMA standard guidelines.

Effluent discharge points located midstream of Sosiani River release various types of pollutants into Sosiani River which lead to changes in physico-chemical properties of water quality. There is significant difference in seasonal variations in physico-chemical properties of water quality along Sosiani River.

\subsection{Recommendations}

The County government of Uasin Gishu, Water Resource Authority and National Environment Management Authority should compel the owners of facilities discharging effluent into Sosiani River to channel it into the sewer lines or build constructed wetlands. Eldoret water and sanitation Company should construct wetlands for tertiary treatment of the waste water from Huruma sewage treatment plant discharged into Sosiani River and relocate Huruma dumpsite away from the banks of Sosiani River to reduce leachates draining into this river.

There should be regularly monitoring of effluent discharge into the river and enhance enforcement of the waste water management regulations by relevant authorities.

The County government of Uasin Gishu and Eldoret Water and Sanitation Company should channel storm water from Eldoret town into Huruma effluent treatment works for treatment before it is released into Sosiani River.

Sewerage systemin Eldoret town should be extended to include informal settlements along Sosiani River to reduce pollution.

\section{References}

i. APHA, (2017). Standard Methods for the Examination of Water and Wastewater (23rd Ed.). Washington DC: American Public Health Association

ii. Bello, O. O., Osho, A., Bankole, S. A., \& Bello, T. K. (2015). Bacteriological and Physicochemical Analyses of Borehole and Well Water Sources in Ijebu-Ode South-Western Nigeria. International Journal of Pharmacy and Biological Science, 8, 18-25.

iii. Burton, A. Jr., \& Robert, P. (2001). Storm Water Effects Handbook: A Toolbox for Watershed Managers, Scientists, and Engineers. New York: Lewis.

iv. Chennakrishnan, C., Stephen, A., Manju, T., \& Raveen, R. (2008). Water Quality Status of Three vulnerable Freshwater Lakes of Suburban Chennai India. Chemical Biological and Physical Sciences, 5, 3355-3360.

v. Goel, P. K. (2006). Water Pollution: Causes, Effects and Control. New Delhi, India: New Age International.

vi. Hogan, M. (2010). Water Pollution Encyclopaedia of Earth Topic ed. Mark McGinley Ed in Chief Cleveland, Washington DC: National Council on Science and the Environment.

vii. Kudret, E. \& Ilker, M. (2011). Water Quality: Physical Chemical and Biological Characteristics. Washington DC: Nova.

viii. Maina, C. W., Mutua, B. M., Oduor, S. O. \& Randa, J. M. (2010). Water Quality and Self-Purification Ability of Njoro River. Egerton Journal of Science and Technology, 10, 123-138.

ix. McKinney, M. L. \& Schoch, R. (2003). Environmental Science Systems. Burlington: Jones and Barlett.

x. Michael, E. G. \& Douglas, E. J. (2004). Statistical Tools for Environmental Quality Assessment. New York: John Wiley and Sons.

xi. Mosley, L., Sarabjeet, S., \& Aalbersberg, B. (2004). Water Quality Monitoring in Pacific Island Countries: Handbook for Water Quality Managers, Laboratories, Public Health Officers and Water Engineers. Fiji Islands: University of the South Pacific Suva.

xii. Moyo, N. A. G. (2013). Analysis of Chemical and Microbiological Quality of Groundwater from Boreholes and Shallow Wells in Zimbabwe. Journal of Physics and Chemistry of the Earth, 66, 27-32. 
xiii. Mugenda, O. M. \& Mugenda, A. G. (2003). Research Methods: Quantitative and Qualitative Approaches (2nd Ed). Nairobi, Kenya: ACTS Press.

xiv. Seth, O. N., Tagbor, T. A., \& Bernard, O. (2014). Assessment of Chemical Quality of Groundwater Over some Rock types in Ashanti Region, Ghana. American Journal of Science and Industrial Research, 5, 1-6.

xv. Suthar, S., Singh, S., Sheoran, A., Garima, M. \& Jai, S. (2012). Physical Chemical and Microbiological Characteristics of Water in Different Sites in Pali District, Rajasthan India. Journal of Chemical Biological and Physical Sciences, 2 , 1061-1066.

xvi. Thivya, C., Chidambaram, S., Thilagavathi, R., Nepolian, M., \& Adithya, V. S. (2014). Evaluation of Drinking Water Quality Index and its Seasonal Variations in hard Rock Aquifers of Madurai District, Tamil Nadu, India. International Journal of Advanced Geosciences, 2, 48-52.

xvii. Trivede, P., Bajpai, A., \& Thareja, S. (2010). Comparative Study of Seasonal Variations in Physico-chemical Characteristics of Drinking Water quality in Kanpur, India. Journal of Natural Science, 8, 11-17.

xviii. UN, (2003). Water for People, Water for Life: A Joint Report by the 23 UN Agencies on Freshwater, UN World Water Development Report at the 3rd World Water Forum in Kyoto Japan March 2003. Kyoto Japan: UNESCO, Berghahn.

xix. Vaishali, P. \& Punita, P. (2013). Assessment of Seasonal Variations in Water Quality of River Mini, Sindhrot, Vadodara India. International Journal of Environmental Science, 3, 1424-1436.

xx. Vanloon, G. W. \& Duffy, S. J. (2005). Environmental Chemistry: A Global Perspective (22nd Ed). Wiltshire: Antony Rowe.

xxi. Varshney, C. K. (2008). Water Pollution and Management (2nd Ed). New Delhi, India: New Age International.

xxii. WHO, (2011). Guidelines for Drinking Water Quality (4th Ed). Geneva, Switzerland: WHO.

xxiii. WHO, (2016). The Situation of Water Related Infection Diseases in the Pan-European Region. World Health Organization Report, August 2016. Geneva, Switzerland: WHO.

xxiv. WHO, (2017). Progress on Drinking Water Sanitation and Hygiene by 2015. World Health Organization Report. Geneva, Switzerland: WHO.

xxv. Yolanda, M. \& Zayas, Z. P. (2007). Water Sampling: Traditional Methods and New Approaches in Water Sampling Strategy. Trends in Analytical Chemistry, 26, 986-991. 